\title{
Democracy and New Media in the European Union: Communication or Participation Deficit?
}

\author{
Asimina Michailidou
}

\begin{abstract}
At the heart of most academic and political debates regarding the future of the European Union lie three key ideas: openness and transparency; citizens' participation in the decision-making process; and democratic legitimacy. Scholars and EU policy-makers have advocated the use of new media, particularly the Internet, in the democratising process of the EU. This article focuses on the top-down aspect of the online European public dialogue and the opportunities that the EU's public communication strategy offers to citizens for involvement in shaping the Union's political nature. Following a 'multi-method' approach for the gathering of empirical data, the Internet's role in the EU's public communication strategy is examined here from four aspects: the European Commission's public communication policies (document analysis); the Commission's implementation of its online policies (website analysis); their impact on key Internet audiences (user survey); and the views of policy-makers (semi-structured interviews with senior Commission officials).
\end{abstract}

THE ROLE OF THE INTERNET AND CITIZENS' PARTICIPATION IN BUILDING THE political identity of the European Union (EU) has never featured more prominently in public debates regarding the future of the EU than during the "period of reflection" (2005-2007) that followed the rejection of the Treaty establishing a Constitution for Europe by the French and Dutch citizens. The negative referenda spurred the EU institutions into action, with the Commission notably producing Plan D for Democracy, Dialogue and Debate only months after the 'No' vote in France (COM(2005)494, final). This document marked a new era in EU governance and public communication policy reforms that aim to increase the EU's democratic legitimacy through increased openness and transparency of the Union's decision-making processes.

Specifically with regard to the EU's public communication, the Commission's new, and widely publicised, strategy has at its heart the strengthening of communicative and collaborative linkages with civil society and the public, in an effort to enhance informed debates on EU issues and widen participation in the consultation stages of decisionmaking. The ultimate goal, however, appears to be far more challenging: The creation

The present article draws on data collected as part of my doctoral thesis (Michailidou 2008b) and of my research within the ESRC-funded "CONSTITUTION" project (Michailidou 2008a; 2007). Funding support from the ESRC for the CONSTITUTION project (RES-000-23-0866; EurPolCom 2008) is gratefully acknowledged. I would also like to thank colleagues working on this project.

The ESRC Constitution project is part of the ESF (European Science Foundation) Project "Building the EU's Social Constituency: Exploring the Dynamics of Public Claims-Making and Collective Representation in Europe". The British study (Paul Statham, PI, Julie Firmstone and Asimina Michailidou) is conducted in collaboration with partners in Norway (Hans-Jörg Trenz, ARENA Oslo), Germany (Klaus Eder, Humboldt University) and Spain (Agustín José Menéndez, Universidad de León). See also http://www2.hu-berlin.de/struktur/constituency/Startseite/home.htm. 
of a European public sphere, where citizens not only debate EU issues but participate in a constant and direct open dialogue with EU officials and policy-makers (see $\operatorname{COM}(2006) 211$, final; $\operatorname{COM}(2006) 212$, provisional version; $\operatorname{COM}(2006) 35$; $\operatorname{COM}(2007) 568$, final; SEC(2006)1553). This is a clear shift from the previously information-oriented policy, with Internet-enabled interactive communication featuring at the core of the Commission's line of action.

As the Commission's efforts to reconnect with the European public have coincided with the Constitutional process, there seems to be an obvious link between the shock the EU establishment experienced by the rejection of the Constitutional Treaty by the French and Dutch publics and the turn in the EU's public communication strategy towards more dialogue-oriented actions. But is the failed Constitutional Treaty the only cause of change in the EU's communicative processes, or are there other, less obvious, factors that need to be considered? What exactly does citizens' participation mean in terms of the Commission's official rhetoric and for EU officials? How is the role of Internet-enabled communication in the EU's decision-making process understood and defined in policy documents and by EU policy-makers alike? What do the recipients of the policy (i.e. online EU publics) think of the Commission's efforts? Crucially, can the analysis of the Commission's public communication strategy offer an insight into the reasons that have led the EU, three years after the Constitutional crisis, to a similar ,dead-end' situation, this time caused by the Irish 'No' vote to the ratification of the Lisbon Treaty, despite the Commission's well-documented commitment to bridge the gap between Europeans and the EU institutions?' ${ }^{1}$ These questions are at the heart of this article, which maps the impact of new communication technologies on the Commission's public communication strategy in the $21^{\text {st }}$ century.

\section{New media and democracy: A theoretical model}

This article draws on and seeks to advance strands of governance and democratic theories related to the case of the EU polity (Kohler-Koch and Rittberger 2007; Richardson 2006) by combining these with an approach that outlines new communication technologies as a key factor for change in international politics (see Chadwick 2006). In particular, the theoretical framework that underpins this paper is concerned with aspects of democratic legitimacy of EU governance and its connection with the concept of the European public sphere(s). Scholars by and large agree that a European public sphere or a network of Europeanised, interrelated national public spheres is needed in order for the EU to achieve the desired democratic legitimation (for example, Eriksen and Fossum 2002; Habermas 2004; Pfetsch 2004; Weiler 1996), although there is no consensus on whether the EU's democratic deficit is the cause or result of an absent/deficient European public sphere (Michailidou 2008b).

The correlation of the EU's democratic deficit with European public sphere(s) is instrumental in contextualising the role of public communication in democratising EU governance: The "chain of communication linkages" between political institutions (EU, trans-European, foreign EU, national, regional) and their citizens is prerequisite for increased visibility of the decisions taken by political actors (Statham et al 2005). Public visibility is, in turn, necessary for rendering political actors more accountable to the public (ibid.). For Beetham and Lord it is precisely the degree, level and type of participation by civil society actors within a communicated field of politics, for example when compared to the involvement of elites, that gives important empirical

\footnotetext{
1 The Irish public rejected the Treaty of Lisbon by referendum on 12 June 2008. Unlike the Constitutional Treaty, this time around Ireland was the only EU member-state to hold a referendum for the ratification of the Treaty of Lisbon. All other member-states have/are following a parliamentary vote ratification process. At the time of the Irish referendum, 19 other member-states had already ratified the Treaty, while the UK was the first country to proceed with the ratification of the Treaty after the negative Irish referendum. For more information on the Treaty of Lisbon, see The European Union 2008.
} 
information on the scale, nature and location of the "democratic deficit" (Beetham and Lord 1998 in Statham et al 2005). Defined within this context, accountability and openness then become core preconditions of democratic legitimacy (ibid.): Communicative linkages among political actors not only indicate the degree of emergence of a European demos, but also act as safeguards of accountability and democratic legitimacy. Consequently, for the EU institutions a first step towards democratic legitimation is to establish public dialogue between the EU decisionmakers and the public, with the latter's feedback incorporated in the decision-making process (Michailidou 2008b). This is the role that public communication strategies by definition fulfil (Michailidou 2008b).

Building on this definition of public communication as a facilitator of democratisation, this paper aims to verify the following hypothesis: the Internet can have a democratising effect on the public sphere. Because of the Internet's ability to bypass ethno-cultural, linguistic and geographical boundaries that several scholars have argued in favour of the democratising potential of this communication medium (Coleman and Gøtze 2001; Smith 2004) and have envisaged an all-inclusive online public sphere, based on the Habermasian normative model (Jordan 2000; Poster 1995). Undeniably, there is a gap between this optimism of early theorists who heralded the coming of a new era in politics and communication upon the Internet's arrival, and today's online reality, regarding which most data suggests that it is mainly Western, male and young users who are benefiting from this new medium so far (Michailidou 2008b). Nevertheless, there is also evidence that this gap between theory and reality online is closing more quickly than anticipated and the fact remains that the Internet does offer the possibility of an all-inclusive, democratic public sphere: The unprecedented speed with which this communication medium has become an integral part of the economic and social infrastructure for the majority of its users allows for such optimism today see (De Rosa et al 2007). Crucially, today's Web community has migrated from using the Internet to building it (the so-called Web 2.0 era) (De Rosa et al. 2007). Within five years from first appearing online, the number of active weblogs had risen to over 70 million in March 2007 (Sifry 2007). Internet users today are not just looking for information; they "make" information and actively participate in social networks and online forums (Sifry 2007).

In the case of the EU, the Internet offers a viable alternative to an offline, more conventional media-regulated communicative platform. Its key characteristics of identity fluidity, ability to bypass communication obstacles, as well as geographical and time-related barriers, render it an accessible medium of communication for a denselypopulated, multi-cultural, multi-lingual polity with a complex institutional structure, such as the EU (Michailidou 2008b). For the same reasons, the Internet is considered instrumental in decision-making at a European level, for it enables deliberative democracy and broader citizens' participation (see Engström 2002; Leonard and Arbuthnott 2001; Weiler 1999). Moreover, regarding the more practical issue of Internet accessibility, the Commission is taking direct action in order to cover the divide between Internet-haves and Internet-have-nots with the i2010 initiative, a Lisbon Agenda package of policies aimed at harnessing the potential of ICT to drive innovation and productivity in Europe (Commission of the European Communities $2008 \mathrm{k}$. ${ }^{2}$ In terms of infrastructure and service availability, broadband penetration, for example, stands at 99.2 million lines in the EU, ahead of US and Canada (81.6 million) and Japan and Korea (43.1 million) (Commission of the European Communities 2008: 5).

\footnotetext{
${ }^{2}$ In 2000 the Commission first introduced a set of measures and actions that aimed to transform the EU in the world's most dynamic and competitive economy by 2010 , known as the Lisbon strategy. In 2005 the Commission simplified and relaunched the strategy as the Lisbon Agenda, refocusing it on jobs and growth (Commission of the European Communities 2008h). i2010 was formed within the framework of the Lisbon Agenda. With this the Commission aims to '1) establish a European information space, 2) reinforce innovation and investment in ICT research; and 3) promote inclusion, public services and quality of life' (Commission of the European Communities 2008k: 3). See also Commission of the European Communities 2008i.
} 
Overall, 24 member states have reached and surpassed the Lisbon Agenda targets aimed at making the region the world's most dynamic and competitive knowledge based economy by 2010, while the remaining three (Greece, Romania, Bulgaria) are closing in the gap rapidly too (Eurostat 2008).

\section{From an "Information policy for the EU" to "Communicating Europe in partnership"}

In this context, I have used a multi-method approach to gather original data on four aspects of the Internet's role in the EU's public communication strategy: the European Commission's public communication policies (document analysis); the Commission's implementation of its online policies (website analysis); their impact on key Internet audiences (user survey); and the "organisational culture" for policy-making (semistructured interviews with senior Commission officials). ${ }^{3}$

With regard to the official Commission rhetoric regarding the role of the Internet, this article examines the EU's Online Public Communication Strategy as it is set out in the wider EU Information and Communication Strategy documents, produced by the Commission from 2001 (when the first such document was published) onwards (Michailidou 2008b). Relevant documents produced by the Council of the European Union (Council), the European Parliament (EP), the Committee of the Regions (CoR) and the European Economic and Social Committee (EESC) were also consulted to identify the other EU institutions' position on the Commission's proposed strategy (Michailidou 2007). The documents can be divided in three distinct periods, namely 2001-2004, 2004-2007 and 2007 to date, which reflect the three stages in the Commission's strategy development from information- to communication-orientated. A list of all Commission documents reviewed can be found in the Annex. ${ }^{4}$

\section{1-2004: An Information strategy for the EU}

In the early days of EU public communication policy-making, the Commission focused primarily on improving the quantity, quality and accessibility of information on EU issues. Subsequently, it proposed synergies and cooperation with national media, national governments and civil society actors, who would act as credible mediators between the EU and the general public. While recognising that there are issues of transparency, openness and accountability of EU institutions and a need for greater citizens' participation in the EU decision-making process (Commission of the European Communities 2001b; 2002), the documents of this period are based on the argument that the public's lack of information or misinformation about the role and actions of the EU institutions lie at the heart of the public's suspicion towards the EU (see Commission of the European Communities 2001a: 18; 2001 b: 3 and 7; 2002: 6).

Consequently, improved democratic governance and increased transparency and openness of the EU decision-making process are directly linked with an increased flow of information regarding EU actions. The Internet, particularly the EU's main online portal, EUROPA (Commission of the European Communities 2008e), ${ }^{5}$ is seen as an integral tool in this process, with the Commission using terms such as "e-Commission", "e-Europe" and "e-governance" to define the institution's passage to $21^{\text {st }}$ century public

\footnotetext{
${ }^{3}$ The data was collected as part of my doctoral thesis (Michailidou 2008b) and of my research within the ESRC-funded "CONSTITUTION" project (Michailidou 2008a; 2007).

${ }^{4}$ For a full list of all EU documents reviewed see Michailidou 2007 and 2008b.

${ }^{5}$ EUROPA was initially launched on the Commission's initiative in 1995 . Following a suggestion from the European Parliament, the Secretaries-General of all institutions set up a Task Force in 1997 which subsequently developed into the Inter-institutional Internet Editorial Committee, with the Commission providing the chair.
} 
communication, always with a focus on information provision rather than dialogue (for example, Commission of the European Communities 2001a).

\section{4-2007: Going local}

A change in the direction of the Commission's public communication strategy can already be detected in 2004. Less obviously in the Communication from the Commission on Implementing the Information and Communication Strategy for the European Union (Commission of the European Communities 2004), more clearly and extensively in The Commission's contribution to the period of reflection and beyond: Plan-D for Democracy, Dialogue and Debate (Commission of the European Communities 2005b), the Commission turned to two-way communication with the public, in an attempt to bring EU institutions closer to the public. The focus on direct interaction with the EU public was established in 2005, when "going local" became the Commission's new public communication motto (see Commission of the European Communities 2005a; 2005b; 2006d).

Civil society, national media and member states are still identified as key partners in the implementation of the Commission's communication strategy, but the White Paper on Communication (Commission of the European Communities 2006d) also focused on matching the EU's communication policy to the EU public's concerns and expectations of 'prosperity, solidarity and security in the face of globalisation' (ibid.: 2). Addressing the issues that concern citizens is a crucial prerequisite, according to Leonard and Arbuthnott (2001), if the EU's institutions are to become more democratic. Also, the Commission's Plan D had earlier identified the promotion of citizens' participation in the democratic process as one of the four broad areas of action required to help regain the EU citizens' trust towards the EU institutions and address issues of democratic legitimation, accountability and openness within the EU (Commission of the European Communities 2005b: 18).

Within the post-Constitution policy framework, the Internet is once more identified as one of the key facilitators of two-way communication between citizens and the EU, as opposed to the previously proposed top-down information flow. For example, in addition to the proposed actions regarding the enhancement of the EU's online portal EUROPA, the White Paper on Communication recommends that all EU institutions should complement their websites with online forums and hold joint open debates similar to the EP debates, where officials will accept comments and questions from the public and journalists (Commission of the European Communities 2006d: 6-8). Despite these actions, and in spite of recognising that further citizen participation in EU matters and greater openness of the decision-making process are necessary to restore the public's trust in the EU institutions, the Commission still does not acknowledge the democratic deficit attributed to the EU institutions as real. Instead, all public communication documents examined here refer to it as a "perceived" deficit caused by citizens' complete lack of or limited information on what the EU does (indicatively see Commission of the European Communities 2008a: 1; 2006d: 1 and 4; 2005b: 9; 2002: 4).

It is necessary here to also note that the impact of the Constitutional process on the Commission proposals of the period 2004-2007 is evident: Several of the documents of this period were produced specifically in response to the failed ratification process, in an effort to identify and address the causes of the citizens' distrust towards attempts for EU institutional reform. At the same time, structural changes within the Commission (establishment of a separate Directorate-General Communication in 2004) and a new College of Commissioners that took on its duties in late 2004 have also contributed to the shift of the Commission's public communication strategy. Margot Wallström was appointed Commission Vice President with responsibility for Inter-institutional Relations and Communication and has since driven these changes in the policy direction from the start. 


\section{7-to date: Communication in partnership}

More recently, in 2007-2008, the Commission's "going local" strategy has been reinforced and expanded to introduce a new era of "Communicating Europe in partnership" (Commission of the European Communities 2007b). With the Treaty establishing a Constitution for Europe (The European Union 2004) amended and repackaged as the Treaty of Lisbon (The European Union 2007), the Commission is now focusing on the concept of active citizenship. This is understood as a series of actions, such as public-dialogue forums open to all citizens and more possibilities for citizens to give feedback in all stages of the policy-making process, which have as primary aim the strengthening of the European Union's democratic processes (see Commission of the European Communities 2007a; 2007b; 2008c). The end result that the Commission seems to be aiming for is the development of a democratic European public sphere through the creation and nurturing of "exchanges, debates and understanding between European institutions, the general public, organised civil society and specialised audiences at European, national, regional and local levels". (Commission of the European Communities 2007b: 6). Nevertheless, no explicit reference is made to the "democratic deficit" argument, and the main responsibility for "communicating Europe" to its citizens is still left with the member states.

Upon closer inspection, however, the Commission's strategy of "active citizenship" in all its post-Constitution versions remains anchored on the principle that increased information about the EU amounts to greater understanding of the Union and, consequently, to a more democratic debate about the future of the EU. No other document illustrates this more clearly than the Citizen's Summary of the Commission's re-launched Plan D for Democracy, Dialogue and Debate:

The Commission wants to:

- create a citizens' ownership of EU policies, to make them understandable and relevant, and to make EU institutions accountable and reliable to those they serve;

- stimulate a wide and permanent debate on the future of the European Union between the democratic institutions in the EU and people from all walks of life, both at country and EU level;

- empower citizens by giving them access to information so that they may be in a position to hold an informed debate on EU affairs" (Commission of the European Communities 2008a: 1).

The Commission's belief in the effectiveness of such a public communication strategy is certainly not new and is rooted in the association of citizens' disinterest and disengagement from politics with the lack of information and understanding of how the EU works (Commission of the European Communities 2008a: 1).

The above Citizens' Summary also highlights the one crucial new element that the Commission introduces in its Lisbon Treaty-era strategy: "Citizens who are consulted by the EU institutions should be able to debate with policy makers. It should be easy to trace the impact of their views throughout the EU decision-making process" (Commission of the European Communities 2008a: 1).

The Commission thus indicates that it has taken into consideration a widely-expressed criticism on its post-Constitution public communication proposals: Engaging in public dialogue with civil society the general public cannot have any meaningful impact on the EU's democratic legitimacy unless the outcomes of this dialogue are somehow formally incorporated in the decision-making process.

In this context, the Internet becomes "a tool of involvement" (Commission of the European Communities 2007a: 4). For the first time a Commission consultation document is dedicated to the potential of the Internet as a means of democratisation (Commission of the European Communities 2007a: 4) and proposes actions not only in 
relation to the improvement of the EU's online portal EUROPA but also with regard to the latest possibilities of online interaction, the so-called Web 2.0 functions, such as media sharing and blogs. Despite this, what remains unspecified in this latest era of the Commission's public communication strategy are the exact ways in which the feedback from civil society organizations and citizens will impact on the modus operandi of the Union.

\section{From an "Information policy" to...even more information for the EU: Online implementation}

Using the main points of the Commission's proposed Information and Communication Strategy described above as a guide for analysis, three official Commission websites were monitored for a period of twenty four weeks in 2004-2005, namely EUROPA, ${ }^{6}$ European Union @ United Nations, ${ }^{7}$ and European Union- The Delegation of the European Union to the USA ${ }^{8}$ (Michailidou 2008b). EUROPA is the EU's official portal, linking the websites of all its institutions, delegations, committees and so on, as well as providing access to legal documentation, general information on the EU and specialised information targeting specific groups (for example, young people and women). The website was therefore chosen for this study as it is the EU's main online public communication tool. On the other hand, EURUNION is a website targeted at a non-EU general audience, i.e. the US public, and was therefore chosen as a sample of the EU's external public communication strategy online. Finally the EU@UN website is a sample of targeted online communication, aimed at a specialised audience (UN diplomats, state representatives etc) and it was chosen as a control website (Michailidou 2008b).

Here, the focus of the findings concerns the EU's main portal, EUROPA. The other two websites fall under the umbrella of external public communication/public diplomacy and they do not directly contribute to or facilitate the European public sphere(s), not have they been identified by the Commission as tools for the democratisation of the EU's governance processes. ${ }^{9}$ What emerged from the analysis of the EUROPA data was a) the Commission's adherence to its commitment of providing detailed information on all aspects of EU institutions and actions; and b) at the same time, a gap between policy and online implementation regarding interaction and facilitation of public dialogue (Michailidou 2008b).

Specifically, when it came to implementing the Commission's commitment to enhancing public dialogue and encouraging the emergence of a European public sphere, interaction with EU officials was only available in the form of generic email addresses, as Figure 1 illustrates below. As a result, despite the Commission's commitment in all its EU Information and Communication documents discussed earlier (see Annex, for a full list of documents reviewed), the Internet was not found to be given a key role in enhancing and facilitating the public dialogue between EU institutions in its practical implementation (Michailidou 2008b).

\footnotetext{
${ }^{6}$ http://europa.eu

${ }^{7}$ http://www.eu-un.europa.eu/home/index en.htm

${ }^{8}$ http://www.eurunion.org/eu/

9 The other two Commission websites monitored during the same period, in order to allow for comparative analysis of the EUROPA findings, were EURUNION (Commission of the European Communities 2008f) and EU@UN (Commission of the European Communities 2008g).

The monitoring took place for twelve weeks in 2004 and twelve weeks in 2005. During the period 13 March 2004 to 10 June 2004442 links were coded on the EUROPA homepage, 979 links on the EURUNION homepage and $\mathbf{6 0 9}$ links on the EU@UN homepage. During the period 3 May 2005 to 20 July 2005 there were $\mathbf{3 7 2}$ links found and coded on the EUROPA homepage, 1011 on the EURUNION one and 658 on the EU@UN homepage.
} 


\section{Figure 1: Types of interactive communication found on EUROPA, EU@UN and EURUNION homepages (Michailidou 2008b: 134).}
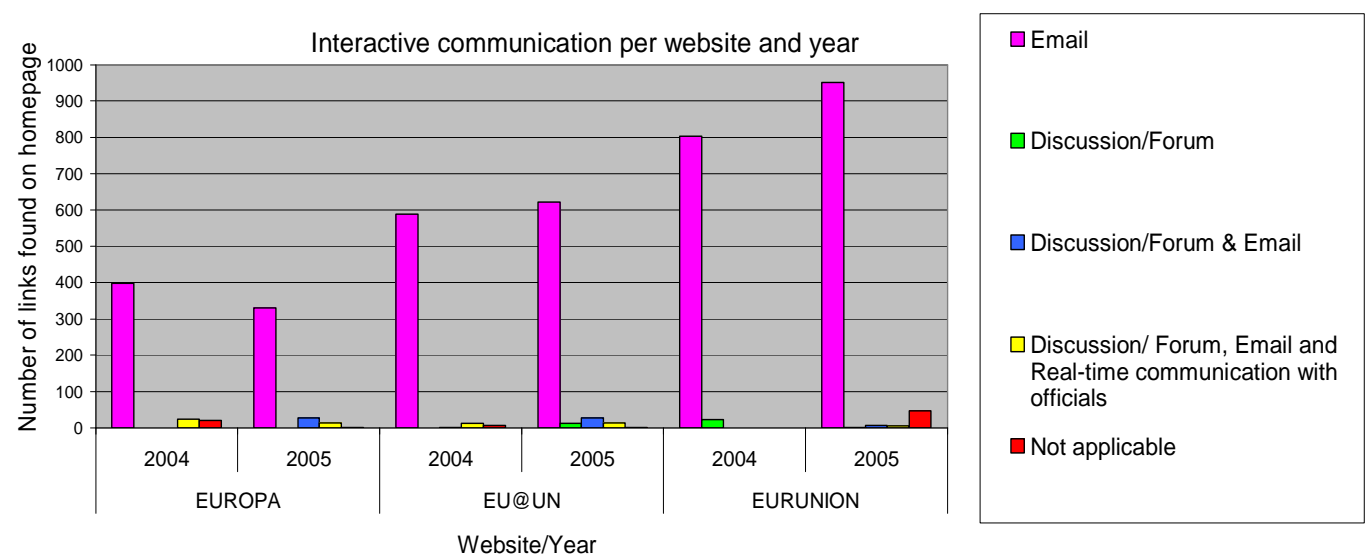

More specifically, during the 2004-2005 monitoring period, online public dialogue was only recorded in 2004 via the permanent online discussion forum called "Futurum" (Futurum public forum) on the EUROPA website. Futurum reached a total of 2,343 contributions to its two political debates regarding the EU's Convention on the future of Europe by the end of the twelve-week monitoring period in 2004, averaging approximately 100 contributions per topic per week. ${ }^{10}$

Besides this, the analysis of EUROPA's homepage found that the EU's online public communication was focused on politics than financial and social issues, as Table 1 below shows. In contrast to that, recent Eurobarometer surveys show that social issues such as unemployment and social security concern Europeans the most, as the majority believes these issues have direct impact on their everyday life but that the EU is not doing enough in these areas (Eurobarometer 2006b; Eurobarometer 2006c). The Commission has also identified such social issues as "priority" ones in most of its EU Information and Communication documents (see Commission of the European Communities 2008b; 2007b; 2006. In this respect, the EU's online public communication also failed to meet the Commission's aim to match its messages to the public's priorities during the crucial 2004-2005 period, as these were identified by the relevant Eurobarometer surveys (Eurobarometer 2006b; Eurobarometer 2006c).

Table 1: Most frequently covered categories of permanently available information linked to the homepage of EUROPA (Data source: Michailidou 2008b).

\begin{tabular}{|l|l|l|}
\hline Most frequently covered topics found on permanent links to EUROPA's homepage \\
\hline Categories & $\mathbf{2 0 0 4}$ & $\mathbf{2 0 0 5}$ \\
\hline Political issues & $\begin{array}{l}\text { EU internal affairs } \\
296 \text { links }\end{array}$ & $\begin{array}{l}\text { EU internal affairs } \\
207 \text { links }\end{array}$ \\
\hline Financial issues & $\begin{array}{l}\text { EU internal trade/ } \\
\text { development } \\
180 \text { links }\end{array}$ & $\begin{array}{l}\text { EU internal trade/ development } \\
122 \text { links }\end{array}$ \\
\hline Social issues & $\begin{array}{l}\text { Work-related issues } \\
200 \text { links }\end{array}$ & $\begin{array}{l}\text { Work-related issues } \\
147 \text { links }\end{array}$ \\
\hline $\begin{array}{l}\text { Total number N of links } \\
\text { examined } 11\end{array}$ & 442 & 372 \\
\hline
\end{tabular}

\footnotetext{
10 This number does not include contributions from EU officials, which were clearly indicated on the forum by stating the name of the official and his/her position.

${ }^{11}$ The total sum of links covering each subcategory of issues is higher than the total number $\mathrm{N}$ of links examined, as in most occasions a link was found to provide information on more than one subcategory of issues.
} 
After this study was completed, the Commission launched a new online discussion forum on EUROPA in March 2006, entitled "Debate Europe" (Commission of the European Communities 2008b). This forum is proving to be far more popular than its predecessor (Futurum) as within six months of its launch it received one million hits, while contributions averaged 153 per day in March 2008. In addition, there is clear evidence that the Commission is actively embracing the new generation of Internet communications, such as social networking and social media: Following the example of Commission Vice-President Margot Wallström, six more Commissioners and five European Representations now have their own blogs, ${ }^{12}$ while the EU now also has a dedicated YouTube channel (Commission of the European Communities 2008d).

Nevertheless, these actions have not yet been followed by a formal framework outlining the exact ways in which the public's feedback will be incorporated in the decision-making process. Similarly, less transparent aspects of the EU legislative process, such as the committee-based consultation process preceding the proposal of EU legislation (Comitology), have yet to be opened up or made available online.

It is clear from the above that the EU's Information and Communication Strategy is not yet fully implemented online. While further study is required in order to assess the success of the Commission's latest actions regarding the EU's Online Public Communication Strategy, it is important to gain an insight in the current views of the recipients of the Commission's online communication efforts. Is access to information as important for the online public as it is for the Commission or do online users value two-way communication more? Do online audiences link two-way communication with EU officials with democratic legitimation of the EU institutions?

\section{E-communication or e-information? The online audiences' perspective}

In order to address these questions, an EU website online user survey was conducted over a period of four months (October 2005-January 2006) among 221 Internet users, comprising twenty seven questions, both closed-response and open-end (Michailidou 2008b). The size of the sample was determined by practical constraints, namely the methodological problems of selecting a sample representative of both the global Internet population and offline demographic groups and the enormity of the financial and time-related costs that would arise from pursuing a large-scale online survey. Consequently, a small, specialised sample of individuals who would statistically be more likely to have visited EU official websites and/or online discussion fora (EU or nonEU alike) was deemed more appropriate. The method chosen was that of a nonprobability, 'snowball' type sample.

12 The six Commissioners who have their own blog, apart from Margot Wallström, are:

- Stavros Dimas, Commissioner for Environment;

- Janez Potočnik, Commissioner for Science and Research;

- Mariann Fischer Boel, Commissioner for Agriculture and Rural Development;

- Vladimir Špidla, Commissioner for Employment, Social Affairs and Equal Opportunities;

- Andris Piebalgs, Energy Commissioner;

- Meglena Kuneva, Commissioner for Consumer Affairs.

The five Representations with blogs are the following:

- Belgium (Head: Willy Hélin);

- Finland (Head: Marjatta Hautala);

- Malta (Head: Joanna Drake);

- Netherlands (Head: Ludolf van Hasselt); and

- Spain (Head: José Luis Gonzalez Vallvé).

All of the above blogs can be accessed from http://blogs.ec.europa.eu/ 
The survey focused on what the Commission has invariably defined as "key", "priority" or "silent majority" audiences, such as women and young people. According to the special Eurobarometer surveys on the Future of Europe, it appears that young people and women remain most sceptical about the EU while women are also less likely to participate in an online debate (Eurobarometer 2006b; Eurobarometer 2006c). Furthermore, several Commission documents of the period 2001-2006 emphasise the importance of maintaining and enhancing communication with specialist audiences, for example individuals who may already have a knowledge and/or interest in EU issues (for example, Commission of the European Communities 2001a; 2002; 2004; 2005b; 2006b; 2006c). At the same time, the average Internet user profile, particularly in the EU, is that of a young and educated individual. ${ }^{13}$

The individuals initially contacted regarding the survey were chosen from all of the following categories:

- Individuals with a professional interest/expertise in EU issues and/or within an organisation/institution of EU specialists;

- Individuals with no professional interest in EU issues and/or within an organisation/institution of non-EU specialists;

- Individuals within an organisation/institution or group with a Pro-EU stance;

- Individuals within an organisation/institution or group with an EU-neutral stance;

- Individuals within an organisation/institution or group with an anti-EU stance.

This distinction was necessary in order to obtain as balanced an outcome as possible. In addition to these criteria, an email address was a prerequisite for an individual to be included in the sample.

72 per cent of the respondents were 20-34 years of age, 82 per cent in academic or other professional/managerial positions, 92 per cent were of EU or EU-related/acceding countries and 86 per cent held a university degree. An unexpected 11 per cent of the respondents were either economically inactive or employed in manual/skilled labour and did not fit the profile of economically affluent and/or highly educated Internet users (Michailidou 2008b). ${ }^{14}$ Cross-tabulations revealed that these respondents were among the most proactive in terms of accessing political websites and online forums regarding EU issues. Overall, gender, education, nationality and age were statistically found to have no effect on the respondents' views on the EU websites and the role of the Internet in eliminating the EU's democratic deficit (Michailidou 2008b).

The majority of the respondents were frequent Internet users (96 per cent access the Internet every day), who also visit political/governmental websites on a regular basis (83 per cent of the respondents) with 70 per cent of the male and 39 per cent of the

\footnotetext{
${ }^{13}$ Determining the gender or age of participants in online debates is quite difficult, since identity fluidity is one of the inherent characteristics of the online public sphere, as discussed earlier. However, young and educated individuals fit the average Internet user's profile, thus being amongst the individuals most likely to access the official EU websites and/or participate in an online debate. More specifically, in the case of the EU25, students are proportionally the most regular users of the Internet (78 per cent of total number of individuals). In terms of access any disparities are more due to lack of interest for the medium (45 per cent of EU27 citizens) than to socio-economic inequalities ( 25 per cent of EU27 citizens) according to the latest statistics (Ottens 2006: 3; Eurobarometer 2007: 15-24).

${ }^{14}$ Respondents were asked to determine their level of education choosing among six categories (non completed compulsory education; completed compulsory education; vocational qualification; BA; MA; PhD) and their work position (open-end question; answers were re-grouped under Public Officials EU; Public Officials Non-EU; IT; Professional/Managerial; Skilled Manual/Manual; Unemployed/Economically inactive; Education Professionals; Education: Students; Health. Data was then cross-tabulated in order to determine correlation between education and occupation.
} 
female respondents claiming to access such websites frequently. Of the 221 respondents, 97 claimed that they access online discussion forums frequently, with the majority of those (38 per cent) preferring political public forums (Michailidou 2008b).

Nevertheless, the frequency with which the interviewees normally access EUROPA is very low: On a scale from 1 (Never) to 5 (Every day), the average frequency with which the respondents access this website was 2.7 degrees. The results are unsatisfactory considering this website is the EU's official voice online and meant to address as wide an audience as possible. These ratings appear even poorer when further contrasted with the 40.3 per cent of all respondents who confirmed that they access other EU websites except for EUROPA, such as the European Parliament website, and the 19 per cent who access weblogs regarding EU issues (Michailidou 2008b).

When asked to evaluate EUROPA in terms of quality of information and accessibility, the respondents gave the website mediocre ratings: On a scale of 1 (poor quality) to 5 (excellent quality) it was rated an average 2.9 for accessibility and 3.4 for the information provided on its homepage (Michailidou 2008b: 157). Further analysis of the data showed that 57 per cent of the respondents based their evaluation on the degree of accessibility of the websites; 41 per cent on how interesting the content of the websites was; 16 per cent on the clarity of the message; 14 per cent on how credible they thought the source to be; and 7 per cent on whether the contents had any relevance to them (Michailidou 2008b: 161).

The survey results further highlighted the poor implementation of the strategy online, in terms of the Commission's commitment to deploy the Internet in its efforts to engage in dialogue with the public and support the emerging European public sphere. Only 12 per cent of the respondents thought EUROPA provided adequate opportunities for interaction with EU officials (Michailidou 2008b: 158).

Despite this, the survey data also show that the Commission's public communication policy design is moving in the right direction in terms of acknowledging the EU's democratic deficit and associating this with the need for increased accessibility, transparency, accountability and two-way communication with the public. More specifically, 96 per cent of the respondents agreed that there is a democratic deficit within the EU institutions (Michailidou 2008b: 164). Of particular significance is the finding that the respondents' views justify the Commission's decision to give the Internet a central role in the implementation of the EU's Information and Communication Strategy: 56 per cent of the respondents thought the Internet can play a productive role in eliminating this deficit as opposed to 40 per cent (eighty eight out of 221 respondents) who disagreed with this statement (Michailidou 2008b: 164).

These results are very close to both the Commission's official public communication strategy and the theoretical concept discussed in the beginning of this chapter. Openness, transparency and widened participation in the decision-making process are seen by several scholars as viable possibilities which the Internet offers because of its core characteristics of identity fluidity, endless flow of information and ability to override censorship and physical space and time barriers. Moreover, similarly to the scholars who point to offline socio-economic inequalities functioning as barriers to a truly all-inclusive online public sphere, a significant number of respondents also pointed to inequalities in access as the main factor blocking the Internet's potential to help eliminate the EU's democratic deficit.

\section{EU public communication strategy: Enhancing or undermining democratic structures? The EU officials' view}

Although the online EU website user survey helped to further highlight the gap between the EU's official Online Public Communication Strategy and implementation 
through its main official portal, EUROPA, it produced no evidence of the reasons behind this gap between policy and online implementation. This issue was further investigated through semi-structured interviews with EU officials, conducted over a period of three years (2004-2007)..$^{15}$ In total, 20 interviews were conducted with senior EU officials in key public communication policy-making and policy-implementation positions in:

- The Commission Directorate-General Communication (DG Comm) [9 interviewees];

- The Commission Directorate-General External Relations (DG Relex) [2 interviewees];

- The European Parliament [2 MEPs and 1 MEP advisor interviewed];

- The European Parliament Secretariat-General [1 interviewee];

- The Committee of the Regions [1 interviewee];

- The European Economic and Social Committee [3 interviewees];and

- The Secretariat-General of the Council of the European Union [1 interviewee]. ${ }^{16}$

What emerged from these interviews is that the gap between policy and implementation, insofar as the EU's Online Public Communication Strategy is concerned, can be attributed to two factors: Firstly, practical/technical obstacles and secondly, a contradictory understanding of the concept of public communication within the Commission as well as among the other institutions (Michailidou 2008a; Michailidou 2008b).

More specifically, the Directorate-General Communication has undergone four restructuring exercises since 2001- a process which all Commission interviewees agreed has disrupted the implementation of the EU's public communication strategy. Furthermore, the officials working on the EU's Information and Communication Strategy are in their majority "non-experts in the field of public communication" as one interviewee put it, while another one further explained that "hiring communication experts is not an option" as there is the danger of the Commission being accused of creating a propaganda machine (Michailidou 2008b)..$^{17}$ This situation partly explains the reasons for the very slow embrace of new communication technologies and in particular of the Internet in the implementation of the EU's public communication strategy, despite policy-makers constantly underlining in every EU Information and Communication document the importance of this medium in reaching target audiences.

Furthermore, there is a difference of perception between officials on policy-making level and officials who are charged with implementing the policy with regard to the aims, online target audiences and role of the Internet in the EU public communication strategy. On the one hand, the policy-makers firmly support the concept of target audiences, and feel strongly about the need to approach "difficult" audiences, such as young people and women, online. On the other hand, policy-implementation officials think that the Internet is mainly a tool of communication with EU specialists and individuals and/or institutions with an interest in the EU and its actions. They are, therefore, not convinced that approaching so-called "vulnerable" target audiences, that is disinterested or sceptical audiences, is worth the effort or that it can be successful.

\footnotetext{
${ }^{15}$ As part of my doctoral thesis (Michailidou 2008b) and in the context of my empirical research for the "CONSTITUTION" project (Michailidou 2008a).

${ }^{16}$ The interviews were conducted in 'semi-structured' format. Because of the senior positions held by the interviewees, they are not identified here by name. Where they are directly quoted in this chapter, they are identified as Interviewee 1, Interviewee 2, etc.

${ }^{17}$ In the context of my doctoral thesis, 6 senior Commission officials were interviewed in 2004-2005 in the Commission's Directorate-General Communication and the Commission's Delegation in Washington DC, US.
} 
Besides this, there is reluctance within the Commission to take the lead from the member-states in the implementation of the EU's Information and Communication Strategy.

Interviews with key EU officials as part of the ESRC-funded "CONSTITUTION" project reaffirmed this divide of opinions regarding the role of the Internet (Michailidou 2008a). When asked to evaluate the importance of improving access to information and documents about the EU on the Internet as a factor for improving the EU's legitimacy, Commission officials gave this an average ranking of 2.6 on a scale of 0 (not at all important) to 4 (very important), with the overall average rating of all EU officials interviewed only marginally lower, at 2.5 (Michailidou 2008a: 7), as Table 2 (below) illustrates. $^{18}$

Table 2: Factors for improving EU's legitimacy (Michailidou 2008a) ${ }^{19}$

\begin{tabular}{|c|c|c|c|}
\hline Factors for improving EU's legitimacy & Rank & $\begin{array}{l}\text { Average } \\
\text { value }^{20}\end{array}$ & $\begin{array}{l}\text { Total } \\
\text { valid } \\
\text { answers } \\
21\end{array}$ \\
\hline Quality coverage of the EU in national media & 1 & 3.4 & 13 \\
\hline $\begin{array}{l}\text { Improving communications between EU organisations and the } \\
\text { media }\end{array}$ & 2 & 2.8 & 13 \\
\hline Promoting the benefits of the EU to its citizens & 3 & 2.8 & 13 \\
\hline Promote specific EU policies to citizens & 4 & 2.8 & 13 \\
\hline Reform the EU budget & 5 & 2.6 & 13 \\
\hline $\begin{array}{l}\text { Simplifying decision making processes to make them more } \\
\text { transparent }\end{array}$ & 6 & 2.5 & 13 \\
\hline Strengthening European level civil society & 7 & 2.5 & 13 \\
\hline $\begin{array}{l}\text { Improving access to information and documents about the EU } \\
\text { on the Internet }\end{array}$ & 8 & 2.5 & 13 \\
\hline Strengthening nationally based civil society over Europe & 9 & 2.2 & 13 \\
\hline Giving citizens more access to EU organisations & 10 & 2.2 & 13 \\
\hline Extend the power of the EU Parliament & 11 & 2.3 & 12 \\
\hline Hold EU Council meetings in public & 12 & 2.2 & 13 \\
\hline Improving access to decision making for civil society groups & 13 & 2.2 & 13 \\
\hline Make the Commission more efficient & 14 & 1.8 & 13 \\
\hline Make the Commission more accountable & 15 & 1.8 & 13 \\
\hline Extend the power of national parliaments in the EU & 16 & 1.9 & 12 \\
\hline $\begin{array}{l}\text { Have a President of the Council/establish clear political leaders } \\
\text { of the EU }\end{array}$ & 17 & 1.7 & 13 \\
\hline Establishing an EU Constitution & 18 & 1.6 & 13 \\
\hline Promoting a European identity among citizens & 19 & 1.5 & 13 \\
\hline Establishing an EU wide media & 20 & 1.3 & 13 \\
\hline Holding national referenda to ratify treaties/a Constitution & 21 & 0.9 & 13 \\
\hline Holding EU wide referenda to ratify treaties/a Constitution & 22 & 0.8 & 13 \\
\hline
\end{tabular}

The results also confirm, at first glance, the impact that the Constitutional process, and particularly the negative referenda in France and the Netherlands, has had on the EU

\footnotetext{
${ }^{18}$ In the context of the 'CONSTITUTION' project, 14 senior officials in key decision-making and policyimplementing positions in the Commission, the European Parliament, the European Council, the Economic and Social Committee and the Committee of the Regions were interviewed during the period April-July 2007. Five of the interviewees were senior officials in the Directorate-General Communication and Directorate-General External Relations of the Commission. During the interviews, officials were asked to evaluate 22 factors that could potentially improve the legitimacy of the EU and rank them in order of importance (Michailidou 2008a).

${ }_{19}$ The table is based on aspects of legitimacy using definitions by Lord (2003) and as discussed by Neuhold and Versluis (2004) with regard to the Constitution, as found in Statham et al 2005.

${ }^{20}$ Numbers are rounded to the first decimal digit.

${ }^{21}$ Although the total number of interviewees was 14, one interviewee did not complete this part of the questionnaire and another chose not to respond to two questions on the basis that he did not feel equipped to do so.
} 
institutions. The factors that were considered least important in the legitimation process of the EU by the majority of respondents were the holding of national or EUwide referenda to ratify treaties or a constitution and establishing EU-wide media (Table 2). However, this link between the failed Constitutional process and the officials' views on direct democracy becomes less clear-cut when we look at how the respondents justified their responses.

Starting with public communication and its apparent link with democratic legitimacy, the majority of the interviewees accepted that there is an issue of legitimacy at the EU level which needs to be addressed (10 out of 12 interviewees). At the same time, the majority of EU officials, whether they accept the EU's democratic deficit or not, agreed that better communication with the public is a key factor of improving legitimacy ( 5 interviewees, EP, 3 Commission, EESC) or at least people's perception of legitimacy (2 interviewees, Commission and (CoR), but gave different examples of how they understand improved communication. ${ }^{22}$ For example, Interviewee 10 (EP) pointed to the recently-launched webTV project, for which the EP Secretariat General is responsible and which will be transmitting parliamentary debates and the activities of MEPs and other EU officials online. In contrast to this, another interviewee explained better communication as improving interaction with national parliaments and strengthening the role and activities of the Commission's Representations (Interviewee 3, Commission) (Michailidou 2008a).

Considering the importance that all interviewed EU officials attributed to public communication, one would expect that they would value two-way communication with the public equally highly, particularly as this has had such a central role in all EU public communication documents since 2004 discussed earlier (see Annex for a full list of Commission documents examined). Indeed, nearly all Commission officials were in favour of two-way communication with the public and civil society (four out of five Commission officials interviewed). Nevertheless, the majority of the officials from the other EU institutions remained sceptical of the feasibility and indeed of the legitimacy of such a concept, as Table 3 (below) illustrates.

Table 3: EU officials' views on two-way communication

\begin{tabular}{|l|c|c|}
\hline Institution & $\begin{array}{l}\text { In favour of two-way communication } \\
\text { with civil society and the public }\end{array}$ & $\begin{array}{l}\text { Sceptical towards two-way } \\
\text { communication with civil society } \\
\text { and the public }\end{array}$ \\
\hline Commission & 4 & 1 \\
\hline CoR & 1 & - \\
\hline Council & - & 1 \\
\hline EESC & 1 & 2 \\
\hline EP/MEP & 1 & 2 \\
\hline Total & $\mathbf{7}$ & $\mathbf{6}$ \\
\hline
\end{tabular}

The officials supportive of the two-way communication strategy based their views on the democratising potential that incorporating feedback from collective actors and individual citizens can have on the decision making process. One interviewee (Secretariat-General, Council of the European Union) used the Commission's Green Paper on Climate Change, the first of its kind, as an example of how civil society consultation can result to beneficial, if not groundbreaking, EU legislation. ${ }^{23}$

\footnotetext{
${ }^{22}$ From the remaining 7 respondents, three referred to structural reform and four gave varied answers, ranging from strengthening the process of participatory democracy and simplifying the EU procedures to putting more emphasis on social issues and reforming the political elites in the member-states.

${ }^{23}$ On 29 June 2007 the European Commission adopted its Green Paper on adapting to the impacts of climate change (Commission of the European Communities 2007c), building upon the work and findings of the European Climate Change Programme (Commission of the European Communities 2008j).
} 
Some saw the process as fraught with difficulties yet inevitably moving towards twoway communication. More specifically, interviewees expressed the view that it is not always possible to guarantee citizens' participation or the quality of the opinions brought forward. As Interviewee 3 put it:

\begin{abstract}
one thing that we did was to introduce minimum standards for consultation which means that, for example, the representations in the member states are now involved in the consultations and doing outreach to actually encourage people of all sides of an issue nationally [...] to get involved, to have some kind of impact on what legislative proposals will end up putting forward for that. You can never guarantee that they will use that thing but] you can set up structures and then either, like with the Convention, if you set it up, people have the ability to [have opinions on it], whether people end up doing that, you can't control but you can try and make it easier or more possible for people to do that.
\end{abstract}

It is also worth noting that the two EESC and CoR officials in favour of the strategy expressed the view that two-way communication can be legitimised provided that the role of their institutions in the decision-making process is strengthened.

On the other hand, the officials who appeared sceptical of this shift in public communication strategy mainly focused on the democratic legitimacy of the initiative. In particular, it is the lack of quality guarantee from public/civil society input that concerns EU officials. Respondents pinpointed the lack of representativeness of civil society organisations, and therefore, to their lack of democratic mandate. For this reason, Interviewee 6 (Commission), for example, expressed concerns that:

\begin{abstract}
The concept of direct democracy is slightly demagogical, in my opinion, because we have the institutions, elected, and therefore there exists a legality, which we then question with an opinion which may be coming from lobbies or organised minorities, which are not representative. Representative is the government. Direct democracy is interesting but it cannot guarantee representativeness. So, when we create communication channels we need to take into consideration that these channels may not represent the majority of Europeans. Direct democracy is very fashionable but it should exist avec moderation.
\end{abstract}

\title{
Discussion
}

Over the last seven years the Commission has repeatedly expressed its commitment to promoting dialogue with the general public and civil society and recognises that public communication is a key factor for improving openness, transparency and citizens' participation in the EU decision-making process, directly linking these with the democratic legitimacy of the Union. The Internet, in particular, potentially constitutes an important public communication tool, which allows for the official EU voice to reach the public directly, bypassing national/regional media and participating in a potentially all-inclusive European public sphere.

Nevertheless, the review of official EU public communication documents has shown that the actions proposed to address the issue of the EU's democratic legitimacy are focused on public perception rather than institutional reform. Following this gap in official rhetoric between public communication aims and proposed actions, EUROPA was found not to offer many opportunities for online public dialogue in 2004-2005, with the only interactive debate forum available at the time (Futurum) attracting limited interest and also being suspended during the critical period of Constitutional debates. The Commission's more recent online initiatives are more debate-orientated but a formal framework outlining the way citizens' feedback is incorporated in the decision-making process is unlikely to be produced in the foreseeable future. Viewed under this light, the Commission's proposals for increased Internet-facilitated citizens' participation in the EU decision-making procedures appear more relevant to perception management than democratic legitimation. 
Despite this, the Commission is not alone in its belief that online public dialogue and increased access to information about EU are directly linked with the Union's democratic legitimacy. Online audiences that fall under the umbrella of the Commission's 'priority' or 'vulnerable' communication target groups also believe that the Internet can help eliminate the EU's democratic deficit, mainly through increased access to information about the EU. For the participants of the survey, access to information is vital as it facilitates transparency of the decision-making process and enables citizens to make informed choices regarding their governance system.

From the perspective of the senior Commission officials directly involved with the design and implementation of the EU's public communication strategy, the key findings from the interviews conducted from 2004-2007 suggest that far from trying to introduce a new propaganda machine, this focus on the public's perception of the EU stems from a deep-rooted understanding of democratic legitimacy as directly depending on informed public dialogue. For most interviewees, increased and factual information regarding the EU institutions and the decisions taken at EU level, as opposed to occasional 'tabloid' type of reporting on EU issues, can have a two-fold effect: Firstly, it will help dispel the myth of 'the Brussels bureaucrats' trying to suffocate national sovereignty and will enable EU citizens make informed decisions regarding the future of the Union. Secondly, the increased reporting on EU issues will also increase transparency of the EU decision-making process and will allow for deliberative processes to emerge in the future regarding the EU polity.

On a theoretical level, the views of the EU officials are very close to the scholarly approaches which see in the national media discourses on EU issues the potential 'Europeanisation' of the national public spheres, and consequently, the potential for emergence of a European public sphere (for example, Koopmans et al 2004; van de Steeg and Risse 2007). The assumption laid out in the European Commission's official public communication strategy and among other officials alike is that an increase in positive/accurate media reporting of EU issues would lead to an increased visibility of the issues surrounding European governance in national public debates, i.e. to "intensified communication about European governance" (Latzer and Sauerwein 2006: 17 cited in Trenz 2007: 15). Since public debate of EU issues is closely linked to the legitimacy of EU governance, a common hypothesis among scholars is that increased coverage in national media will allow for greater/closer public scrutiny of the EU institutions, and thus contribute to the legitimization of the Union (Trenz 2007).

However close this approach may be to the Habermasian model of the bourgeois public sphere, where the media contribute to the rational critical debate (Habermas 1989), It does not take into account a fundamental characteristic of the media: They are autonomous organisations that operate under their own institutional rules and culturewhich means that national media will not always provide information on EU issues within the timeframe and context that the EU institutions want. As Trenz points out, "such a linear relationship between growing competencies of the EU and growing public attentiveness to European integration has so far not been corroborated by empirical analysis" (Trenz 2007: 15). For example, the Constitutional process did not generate national and transnational public debates on the future of the EU nor did it increase the opportunities for citizens' views to be heard in the public sphere, to the extent that EU officials had initially hoped (see Firmstone and Statham 2007).

The analysis of the interview data indicates that, rather than having an empirically substantiated basis, the EU officials' belief in the legitimizing potential of the media stems from their understanding of public communication: Whether sceptical or in favour of two-way communication with the public and civil society, interviewees thought that such a process raises issues of representativeness and legitimacy of the EU decision-making procedures and can potentially undermine parliamentary procedures. 
The link between information, communication and democratic legitimacy casts new light on the term "participatory democracy", which is frequently used in EU documents of the post-Constitutional period (see Commission of the European Communities 2008b; 2007b; The European Union 2004; 2008). Referring to the Treaty establishing a Constitution for Europe, ${ }^{24}$ Smismans has already pointed out that the whole debate regarding direct citizen participation in the decision-making process on an EU level has mainly focused on an alternative form of representation (i.e. representation via associations and interest groups) rather than direct participation (Smismans 2004: 128129). The review of the EU's Online Public Communication Strategy and interviews with EU officials corroborate this observation: Holding referenda (a key element of direct democracy) to ratify EU treaties, for example, is not highly rated by EU officials as a democratic legitimacy factor. At the same time, the Commission's proposals for twoway communication with the public focus mainly on providing accurate information on EU actions and increasing information about the profile of EU actors, rather than outlining how the public's input is going to be formally embedded in the EU's decisionmaking process.

New media communication and the Internet in particular have certainly facilitated the shift of the EU's public communication strategy from information to dialogue-oriented actions. Nevertheless, the Commission still appears to vacillate between an informational and a participatory line of action. This inevitably impacts not only on the implementation of the EU's public communication strategy but also on the conceptual framework that shapes the Commission's political outlook on the future of the Union (representative vs. participatory democracy). Whether the informational or the participatory type of Online Public Communication Strategy will supersede in the coming years will also determine whether the Commission is aiming to cultivate public debate or merely to achieve public consensus over the future of the EU.

\section{References}

Chadwick, A. (2006). Internet Politics: States, Citizens, and New Communication Technologies. New York and Oxford: Oxford University Press.

Coleman, S. and J. Gøtze (2001). Bowling Together: Online Public Engagement in Policy Deliberation, London: Hansard Society. Available at: http://bowlingtogether.net/, accessed 25 January 2004.

Commission of the European Communities (2001a). A New Framework for Co-operation on Activities Concerning the Information and Communication Policy of the European Union, $\operatorname{COM}(2001) 354$, final.

Commission of the European Communities (2001b). European Governance- A White Paper, $\operatorname{COM}(2001) 428$, final.

Commission of the European Communities (2002). An Information and Communication Strategy for the European Union, $\operatorname{COM}(2002) 350$, final/2.

Commission of the European Communities (2004). Implementing the Information and Communication Strategy for the European Union, COM(2004)196, final.

Commission of the European Communities (2005a). Action Plan to Improve Communicating Europe by the Commission. Vice-President Margot Wallström website. Available at:

\footnotetext{
24 The EU Constitutional Treaty itself clearly identifies both representative and participatory democracy as fundamental principles of the democratic life in the EU (The European Union 2004: 3435 , articles $1-46$ and $1-47)$.
} 
http://europa.eu.int/comm/dgs/press communication/pdf/communication co m_en.pdf, accessed 14 February 2006.

Commission of the European Communities (2005b). The Commission's contribution to the period of reflection and beyond: Plan-D for Democracy, Dialogue and Debate, $\operatorname{COM}(2005) 494$, final.

Commission of the European Communities (2006a). European policies concerning youth participation and information: Follow-up to the White Paper on a New Impetus for European Youth: Implementing the common objectives for participation by and information for young people in view of promoting their active European citizenship $\{S E C(2006) 1006\}, \operatorname{COM}(2006) 417$, final.

Commission of the European Communities (2006b). Information note from Vice President Wallström to the Commission: Plan D-Wider and deeper Debate on Europe, SEC(2006)1553.

Commission of the European Communities (2006c). The Period of Reflection and Plan D, $\operatorname{COM}(2006) 212$, provisional version.

Commission of the European Communities (2006d). White Paper on a European Communication Policy presented by the Commission, COM(2006)35.

Commission of the European Communities (2007a). Communicating about Europe via the Internet- Engaging the citizens, SEC(2007)1742.

Commission of the European Communities (2007b). Communicating Europe in Partnership, COM(2007)568, final.

Commission of the European Communities (2007c). Green Paper- Adapting to climate change in Europe - options for EU action, COM(2007)354 final.

Commission of the European Communities (2008a). Citizens' Summary: Debate EuropeBuilding on the experience of Plan D for Democracy, Dialogue and Debate. Available at:

http://ec.europa.eu/commission_barroso/wallstrom/pdf/com_2008_158-4summary en.pdf, accessed 30 April 2008.

Commission of the European Communities (2008b). Debate Europe. Available at: http://europa.eu/debateeurope/index en.htm, accessed 25 September 2008.

Commission of the European Communities (2008c). Debate Europe-building on the experience of Plan D for Democracy, Dialogue and Debate, COM(2008)158/4.

Commission of the European Communities (2008d). EU Tube, Available at: http://www.youtube.com/eutube, accessed 29 March 2008.

Commission of the European Communities (2008e). EUROPA- Gateway to the European Union. Available at: http://europa.eu/index en.htm, accessed 14 August 2006.

Commission of the European Communities (2008f). European Union-Delegation of the European Commission to the USA. Available at: http://www.eurunion.org/, accessed 14 August 2008.

Commission of the European Communities (2008g). European Union @ United Nations. Available at: http://www.europa-eu-un.org/home/index en.htm, accessed 14 August 2008.

Commission of the European Communities (2008h). Growth and Jobs. Available at: http://ec.europa.eu/growthandjobs/index en.htm, accessed 15 March 2008.

Commission of the European Communities (2008i). i2010- A European Information Society for growth and employment. Available at: http://ec.europa.eu/information society/eeurope/i2010/index en.htm, accessed 15 March 2008.

Commission of the European Communities (2008j). Living with climate change in Europe. Available at:

http://ec.europa.eu/environment/climat/adaptation/index en.htm, accessed 14 January 2008.

Commission of the European Communities (2008k). Preparing Europe's digital future: i2010 Mid-Term Review, COM(2008) 199 final.

De Rosa, C., Cantrell, J., Havens, A., Hawk, J., Jenkins, L. (2007). Sharing, privacy and trust in our networked world. OCLC Online Computer Library Center. Available at: http://www.oclc.org/reports/pdfs/sharing.pdf, accessed 12 February 2008. 
Engström, M. (2002). Rebooting Europe: Digital Deliberation and European Democracy (Report 4). Brussels: The Foreign Policy Centre in association with the British Council.

Eriksen, E. O. and J. E., Fossum (2002). Democracy through strong publics in the European Union? Journal of Common Market Studies, 40(3), pp.401-424.

Eurobarometer (2006b). The European citizens and the future of Europe: Qualitative study in the 25 Member-States (Report). Available at: http://ec.europa.eu/public_opinion/quali/ql_futur_en.pdf, accessed 14 June 2006.

Eurobarometer (2006c). The Future of Europe (Special Eurobarometer 251/Wave 65.1/TNS Opinion \& Social). Available at: http://ec.europa.eu/public_opinion/archives/ebs/ebs_251_en.pdf, accessed 14 July 2006.

Eurobarometer (2007). E-Communications Household Survey- Summary. Special Eurobarometer 274/Wave 66.3/TNS Opinion \& Social. Available at: http://ec.europa.eu/public opinion/archives/ebs/ebs 274 sum en.pdf, accessed 15 July 2008.

Eurostat (2008). Innovation and research: Level of Internet access- Households (EU and candidate countries). Eurostat. Available at:

http://epp.eurostat.ec.europa.eu/QueenPortletized/display.do?screen=graphicr ef\&output=PNG\&language=en\&product=STRIND INNORE\&root=STRIND INNO RE/innore/ir031, accessed 3 April 2008.

EurPolCom (2008). The impact of EU 'Constitutionalisation on public claims-making over Europe (ESRC Award Ref. RES-000-23-0886). Available at: http://www.eurpolcom.eu/research_projects_const.cfm, accessed 27 March 2008.

Firmstone, J. and P., Statham (2007). Mediated debates about the EU and ratification of the European Constitution in the British Public Sphere. EurPolCom Working Paper Series 15/07. Available at: http://www.eurpolcom.eu/exhibits/paper 15.pdf, accessed 4 October 2008.

Habermas, J. (1989). The Structural Transformation of the Public Sphere. Great Britain: Polity Press.

Habermas, J. (2004). Does Europe need a Constitution? Response to Dieter Grimm. In: E. O. Eriksen, A. J. Menendez and J. E. Fossum (eds). Developing a Constitution for Europe, Oxon/New York: Routledge, pp.19-34.

Jordan, T. (2000). Cyberpower: The Culture and Politics in Cyberspace and the Internet. London/ New York: Routledge.

Kohler-Koch, B. and B. Rittberger (eds) (2007). Debating the Democratic Legitimacy of the European Union. Lanham: Rowman \& Littlefield Publishers.

Koopmans, R., Statham, P., Kriesi, H., Della Porta, D., de Beus, J., Guiraudon, V., Medrano, J., Diez, Pfetsch, B. (2004). EUROPUB.com: The Transformation of Political Mobilisation and Communication in European Public Spheres. Available at: http://europub.wz-berlin.de/Default.htm, accessing 5 March 2006.

Leonard, M. and T., Arbuthnott (2001). Next Generation Democracy: Legitimacy in Network Europe- A framework document (Report 1). The Foreign Policy Centre. Available at: http://fpc.org.uk/publications/, accessed 3 February 2004.

Michailidou, A. (2007). The impact of "Constitutionalisation" on the EU public communication strategy: EU official rhetoric and civil society. EurPolCom Working Paper Series 14/07. Available at:

http://www.eurpolcom.eu/exhibits/paper_14.pdf, accessed 25 March 2008.

Michailidou, A. (2008a). "Constitutionalisation" of the European public sphere- EU public communication, institutional culture and civil society. EurPolCom Working Paper Series 16/08. Available at: http://www.eurpolcom.eu/exhibits/paper 16.pdf, accessed 25 March 2008.

Michailidou, A. (2008b). The European Union online. Berlin: VDM-Verlag Dr Müller.

Ottens, M. (2006). Statistics in Focus: Use of the Internet among individuals and enterprises. Eurostat. Available at: http://epp.eurostat.cec.eu.int/cache/ITY OFFPUB/KS-NP06-012/EN/KS-NP-06-012-EN.PDF, accessed 14 July 2007. 
Poster, M. (1995). Cyberdemocracy: Internet and the Public Sphere. School of Humanities, University of California Irvine. Available at:

http://www.hnet.uci.edu/mposter/writings/democ.html, accessed 23 March 2006.

Richardson, J. J. (2006). European Union: power and policy-making, 3rd ed., Abingdon: Routledge.

Sifry, D. (2007). The state of the live Web (Technorati)- April 2007. Sifry's Alerts- David Sifry's musings. Available at: http://www.sifry.com/alerts/archives/000493.html, accessed 3 April 2008.

Smismans, S. (2004). The Constitutional labelling of "The democratic life of the EU". In: L. Dobson and A. Föllesdal, (eds). Political theory and the European constitution, London: Routledge, pp.122-138.

Smith, G. (2004). The politics of deceit: saving freedom and democracy from extinction. Hoboken, New Jersey: John Wiley.

The European Union (2004).. Treaty establishing a Constitution for Europe, the Official Journal of the European Union, C 310, pp. 1-474, <http://eurlex.europa.eu/LexUriServ/LexUriServ.do?uri=OJ:C:2004:310:0011:0040:EN:PDF>, accessed 3 March 2006.

The European Union (2008). Treaty of Lisbon. Available at: http://europa.eu/lisbon treaty/index en.htm, accessed 29 March 2008.

Trenz, H. (2007). Measuring Europeanisation of Public Communication- The question of standards. Reconstituting democracy in Europe (RECON) Online Working Paper 2007/12.

Available

at:

http://www.reconproject.eu/main.php/RECON wp 0712.pdf?fileitem=5882287, accessed 28 November 2007.

van de Steeg, M. and T., Risse (2007). The Emergence of a European Community of Communication: Insights from Empirical Research on the Europeanization of Public Spheres. Centre for transnational relations, foreign and security policy. Available at: $\quad$ http://www.atasp.de/downloads/eps vandesteeg risse 070513.pdf, accessed 7 September 2007.

Weiler, J.H.H. (1996). European Union: democracy without a demos? Falmer: International Relations and Politics Subject Group, University of Sussex.

Weiler, J.H.H. (1999). The constitution of Europe: "Do the new clothes have an emperor?" and other essays on European integration. Cambridge: Cambridge University Press. 


\section{Annex}

\section{EU public communication official documents reviewed COM and SEC documents}

$\operatorname{COM}(2000) 154$, final. Communication from the Commission to the European Parliament, the Council, the Economic and Social Committee and the Committee of the RegionsStrategic Objectives 2000-2005.

$\operatorname{COM}(2001) 0727$, final. Communication from the Commission on the future of the European Union: European Governance- Renewing the Community method.

$\operatorname{COM}(2001) 428$, final. European Governance- $A$ White Paper.

$\operatorname{COM}(2001) 354$, final. Communication from the Commission to the Council, European Parliament, Economic and Social Committee, the Committee of the Regions on A New Framework for Co-operation on Activities Concerning the Information and Communication Policy of the European Union.

$\operatorname{COM}(2002) 350$, final/2. Communication from the Commission to the Council, the European Parliament, the Economic and Social Committee and the Committee of the Regions on an Information and Communication Strategy for the European Union.

$\operatorname{COM}(2002) 705$, final. Report from the Commission on European Governance.

$\operatorname{COM}(2003) 0216$, final. Report from the Commission on the application in 2002 of Regulation (EC) No 1049/2001 of the European Parliament and of the Council regarding public access to European Parliament, Council and Commission documents.

COM(2003)0276, final- CNS 2003/0116. Commission of the European Communities proposal for a Council Decision establishing a Community action programme to promote active European citizenship (civic participation).

$\operatorname{COM}(2004) 154$, final. Communication from the Commission: Making citizenship work: fostering European culture and diversity through programmes for youth, culture, audiovisual and civic participation.

$\operatorname{COM}(2004) 196$, final. Communication from the Commission to the Council, the European Parliament, the European Economic and Social Committee and the Committee of the Regions on Implementing the Information and Communication Strategy for the European Union.

$\operatorname{COM}(2004) 0552$, final. Communication from the Commission to the Council, the European Parliament, the European Economic and Social committee and the Committee of the Regions on the implementation of an information and communication strategy on the Euro and Economic and Monetary Union.

$\operatorname{COM}(2004) 695$, final. Report from the Commission: Fourth report on citizenship of the Union (1 May 2001 - 30 April 2004).

$\operatorname{COM}(2005) 229$, final. Communication from the Commission to the Council, the European Parliament, the European Economic and Social Committee and the Committee of the Regions "i2010 - A European Information Society for growth and employment".

$\operatorname{COM}(2005) 494$, final. Communication from the Commission to the Council, the European Parliament, the European Economic and Social Committee and the Committee of the Regions: The Commission's contribution to the period of reflection and beyond: Plan-D for Democracy, Dialogue and Debate.

$\operatorname{COM}(2006) 417$, final. European policies concerning youth participation and information Follow-up to the White Paper on a New Impetus for European Youth: Implementing the common objectives for participation by and information for young people in view of promoting their active European citizenship \{SEC(2006) 1006\}. 
$\operatorname{COM}(2006) 211$, final. Communication from the Commission to the European Council: $A$ Citizen's Agenda-Delivering results for Europe.

$\operatorname{COM}(2006) 212$, provisional version. Communication

from the Commission to the European Council: The Period of Reflection and Plan D.

COM(2006)35. White Paper on a European Communication Policy, presented by the Commission.

$\operatorname{COM}(2007) 568$, final. Communication from the Commission to the European Parliament, the Council, the European Economic and Social Committee and the Committee of the Regions-Communicating Europe in Partnership.

SEC(2006)1553. Information note from Vice President Wallström to the Commission: Plan $D$-Wider and deeper Debate on Europe.

SEC(2007)1742. Communication to the Commission: Communicating about Europe Via the Internet-Engaging the Citizens.

\section{Other Commission public communication documents and sources}

Carvounis, P. (2007). Partnerships- How do they work? Workshop 2 "Partnerships between the EU and national authorities: structures, means and tools". Communicating Europe together, 18-19 January 2007, Berlin. Retrieved 4 February 2007, from Vicepresident Margot Wallström website,

http://ec.europa.eu/commission barroso/wallstrom/communicating/berlin post en.ht $\underline{\mathrm{m}}$

Commission of the European Communities (2005a). Action Plan to Improve Communicating Europe by the Commission. Retrieved 14 February 2008, from http://ec.europa.eu/dgs/communication/pdf/communication com en.pdf

Commission of the European Communities (2005b). Annex regarding the Action Plan to Improve Communicating Europe by the Commission. Retrieved 14 February 2006, from http://ec.europa.eu/dgs/communication/pdf/communication_annex_en.pdf

Commission of the European Communities (2005c). Digital Divide Forum Report: Broadband access and public support in under-served areas. Retrieved 15 July 2008, from http://ec.europa.eu/information society/eeurope/i2010/digital divide/index en.htm

Commission of the European Communities (2006b). The cost of the non-Constitution (Commission staff working paper). Retrieved 9 January 2007, from Vice-president Margot Wallström website,

http://ec.europa.eu/commission_barroso/wallstrom/pdf/final_report_21112006_en.pdf

Commission of the European Communities, Directorate General Communication (2006). Retrieved 27 August 2006, from White Paper on a European Communication policy: Have your say! Website,

http://ec.europa.eu/communication white paper/index en.htm

Commission of the European Communities, Press and Communication Service (2001). Communication by the President to the Commission in agreement with Vice-President Neil Kinnock and Mr. Erkki Liikanen: Towards the e-Commission, EUROPA 2nd Generation/ Advanced web services to citizens, businesses and other professional users, $D(2000)$. Retrieved 3 April 2006, from http://ec.europa.eu/dgs/communication/pdf/e2g_en.pdf

EUROPA (2008a). Glossary: Democratic Deficit. Retrieved 18 July 2008, from http://europa.eu/scadplus/glossary/democratic deficit en.htm

EUROPA (2008b). The EU at a glance. Retrieved 14 April 2008, from http://europa.eu/abc/index en.htm

Wallström, M. (2005). Information note from Vice-President: Communicating the Constitution- 10 Concrete Actions by the Commission. Retrieved 23 April 2008, from VicePresident Margot Wallström website, 
http://ec.europa.eu/commission barroso/wallstrom/pdf/communicating constitution en.pdf

Wallström, M. (2008). The EU is strengthening its democracy. Article in Sydsvenska Dagbladet. Retrieved 1 April 2008, from

http://ec.europa.eu/commission barroso/wallstrom/pdf/article 20080218 en.pdf 